\title{
Antimicrobial, Antioxidant and DNA Damage Prevention Effect of Nano-Copper Particles Obtained from Diplotaenia turcica Plant by Green Synthesis
}

\author{
Hamdullah Seçkin* \\ Van Vocational School of Health Services, Van Yüzüncü Y1l University, Zeve Campus, 65080 Van, Turkey
}

Received: 7 November 2020

Accepted: 10 January 2021

\begin{abstract}
Metal nanoparticles have been intensely researched and developed in recent years due to their superior properties. There is a growing interest in economical and environmentally friendly techniques. $\mathrm{Cu}$ metal is preferred in research studies due to its cheapness and effects on human health (such as production of blood cells, oxidation and reduction).

In recent years, the use of plant extracts in nanoparticle synthesis has become quite popular. In this study, we aimed to investigate the antioxidant capacity and protective properties of $\mathrm{Cu}$ nanoparticles obtained by using Diplotaenia turcica plant against damage to pBR322 plasmid DNA. In addition, we investigated the antimicrobial effect of $\mathrm{Cu}$ nanoparticles against Staphylococcus aureus ATTC 29213, Pseudomonas aeruginosa ATCC 27853, Enterococcus faecalis ATCC 29212, Bacillus subtilis ATCC 6633, Bacillus cereus ATCC 10876, Escherichia coli ATCC 25952, Candida albicans ATCC 25952. Diplotaenia turcica plant characterization with $\mathrm{Cu}$ metal $(\mathrm{Cu}$ NPs/Dt) ultraviolet and visible light absorption spectroscopy (UV-vis), fourier-transformed infrared spectroscopy (FT-IR), scanning electron microscopy (SEM), X-ray diffraction (XRD) and energy dispersive X-ray (EDX) analysis. When looking at the antioxidant activity analysis, it is understood that it is a powerful antioxidant. It was determined that $\mathrm{Cu} \mathrm{NPs} / \mathrm{Dt}$ have significant antimicrobial activity. Its effect against some pathogens was found to be stronger than the positive control antibiotic. It was determined by the obtained DNA images that there is a potential to prevent breaks that may occur in DNA depending on the concentration.
\end{abstract}

Keywords: antimicrobial, antioxidant, Diplotaenia turcica; DNA damage, nanoparticle

*e-mail: hamdullahseckin@yyu.edu.tr 


\section{Introduction}

Nanotechnology is a growing field of study in the scientific world to obtain new nanoscale particles [1-5]. Nanoparticles can be prepared using various chemical, electrochemical, radiation, photochemical and biological methods developed in recent years. However, due to the toxicity of materials used in chemical synthesis, it is imperative to use environmentally friendly and non-toxic stabilizing agents in the synthesis of nanoparticles. In this context, biological methods provide a significant advantage in the production of non-toxic nanoparticles compared to physical and chemical methods. In recent years, the use of plant extracts in nanoparticle synthesis has gained popularity due to its simple, non-toxic, cheap and applicability in various fields [6-8]. Metal nanoparticles are being studied extensively due to their unique chemical properties such as catalytic activity, optical properties, electronic properties, antimicrobial activity, antioxidant, anticancer and magnetic properties [913]. Studies have proven that $\mathrm{Cu}$ nanoparticles show strong antibacterial properties and at the same time show effective antimicrobial properties against some pathogens [14, 15]. $\mathrm{Cu}, \mathrm{Zn}$ and $\mathrm{Ag}$ nanoparticles have the ability to inhibit the growth of these microorganisms due to the damage they cause on the membrane of bacterial cells [16]. Synthesized $\mathrm{Cu}$ NPs by using Artemisia haussknechtii leaf extract have been found to have inhibitory effects against Escherichia coli, Staphylococcus aureus and Serratia marcescens bacteria $[17,18]$. It was stated in the study that $\mathrm{Cu}$ nanoparticles show activity against many pathogens and have the ability to reduce bacterial populations to zero [19]. Diplotaenia turcica is an endemic plant that has existed for many years with a woody root structure of about 1.5-2 m long. Diplotaenia turcica, which blooms in white in August, is popularly known as "siyabo" [20]. Diplotaenia turcica plant is used by the people of the region in meals and treatments, as well as in the structure of herby cheese. In addition, Diplotaenia turcica plant is popularly used for diabetes, blood pressure and rheumatic conditions [21].

In this study, CuNPs were synthesized using the extracts of Diplotaenia turcica plant (Cu NPs/Dt), an endemic species that grows in rural areas of Van and using biological synthesis method. Particles with $\mathrm{Cu}$ NPs, Ultraviolet / visible light absorption spectroscopy (UV-vis), X-ray diffraction (XRD), fourier transform infrared spectroscopy (FT-IR), scanning electron microscopy (SEM) and energy dispersive X-ray (EDX) analyzes has been characterized. The antimicrobial effects of synthesized $\mathrm{Cu}$ NPs against some pathogens that cause disease in the human body, the antioxidant level that has an important effect on health, and the activities to prevent damage to DNA have been investigated.

\section{Material and Methods}

\author{
Synthesis of $\mathrm{Cu}$ NPs/Dt
}

Diplotaenia turcica plant, which grows in the higher parts of Hakkari province, was collected properly. Later, he was diagnosed at Van Yüzüncü Y1l University, Faculty of Science, Department of Biology, Herbarium Techniques Laboratory (Herbarium no: Vanf 32858). Leaf parts were removed, washed and left to dry. After drying at room temperature for 15 minutes, the grinding process was performed [22]. For the synthesis of nanoparticles, Gurunathan et al. [23] method was used in a modified form. For the synthesis of $\mathrm{Cu}$ NPs/Dt, 1 $\mathrm{mM} 500 \mathrm{ml} \mathrm{CuSO}_{4}$ aqueous solution was prepared. 100 $\mathrm{ml}$ of Diplotaenia turcica plant leaf extract was allowed to react under constant conditions at room temperature in a $1000 \mathrm{ml}$ flask. Color change occurred in the solution after 40-45 minutes. The resulting solution was centrifuged at $10.000 \mathrm{rpm}$ for 5 minutes and the liquid phase was removed. The remaining solid part in the tubes was subjected to washing with distilled water. The resulting solid part was left to dry in the oven at $48-50^{\circ} \mathrm{C}$ for 2 days. And as a result of this process, nanoparticles were obtained.

\section{Characterization of $\mathrm{Cu} \mathrm{NPs} / \mathrm{Dt}$}

UV measurements were made using the PEL 750 instrument in the wavelength range of $250-800 \mathrm{~nm}$. FT-IR analysis was carried out with a spectrometer device in the wavelength range of $500-4000 \mathrm{~cm}^{-1}$ to identify the functional structures of various molecules in the plant extract. XRD analysis was performed using an X-Ray diffraction diffractometer. The size and morphology of $\mathrm{Cu}$ NPs/Dt were obtained using scanning electron microscopy (SEM, Zeiss SmartEDX).

\section{Antioxidant Activity of $\mathrm{Cu} \mathrm{NPs} / \mathrm{Dt}$}

Which is the extract of the study subject. The DPPH quenching activity of $\mathrm{Cu}$ NPs/Dt was calculated using the previously found method [24]. BHA was used as a positive control in this procedure.

Table 1. Tested microorganisms used in the study.

\begin{tabular}{|c|}
\hline Tested microorganisms \\
\hline Staphylococcus aureus ATTC 29213 \\
\hline Pseudomonas aeruginosa ATCC 27853 \\
\hline Enterococcus faecalis ATCC 29212 \\
\hline Bacillus subtilis ATCC 6633 \\
\hline Bacillus cereus ATCC 10876 \\
\hline Escherichia coli ATCC 25952 \\
\hline Candida albicans ATTC 90028 \\
\hline
\end{tabular}


Table 2. Factors added to pits in electrophoresis process.

\begin{tabular}{|c|c|}
\hline Pit & Factors added to pits \\
\hline 1. Pit & pBR322+ Loading dye \\
\hline 2. Pit & pBR322+ Loading dye $+\mathrm{H}_{2} \mathrm{O}_{2}+\mathrm{UV}$ \\
\hline 3. Pit & pBR322+ Loading dye $+\mathrm{H}_{2} \mathrm{O}_{2}+\mathrm{UV}+50 \mathrm{mg} / \mathrm{L} \mathrm{Cu} \mathrm{NPs} / \mathrm{Dt}$ \\
\hline 4. Pit & pBR322+ Loading dye $+\mathrm{H}_{2} \mathrm{O}_{2}+\mathrm{UV}+100 \mathrm{mg} / \mathrm{L} \mathrm{Cu} \mathrm{NPs} / \mathrm{Dt}$ \\
\hline 5. Pit & pBR322+ Loading dye $+\mathrm{H}_{2} \mathrm{O}_{2}+\mathrm{UV}+250 \mathrm{mg} / \mathrm{L} \mathrm{Cu} \mathrm{NPs} / \mathrm{Dt}$ \\
\hline
\end{tabular}

The experiment was carried out using methanol solutions of $0.1 \mathrm{mg} / \mathrm{ml} \mathrm{DPPH}$. DPPH and $\mathrm{Cu}$ NPs/Dt extract solutions were prepared in 7 different concentrations of $5,10,15,20,25,50$ and $100 \mu \mathrm{g} / \mathrm{ml}$. Cu NPs/Dt extract and positive control $3 \mathrm{ml}$ were taken and DPPH solution was added on them. The mixtures formed in the tubes were incubated for 30 minutes in the dark and at room temperature. At the end of this period, absorbance values were read at $517 \mathrm{~nm}$.

$$
\% \mathrm{I}=\left[\left(\mathrm{A}_{\text {control }}-\mathrm{A}_{\text {sample }}\right) / \mathrm{A}_{\text {control }}\right] \times 100
$$

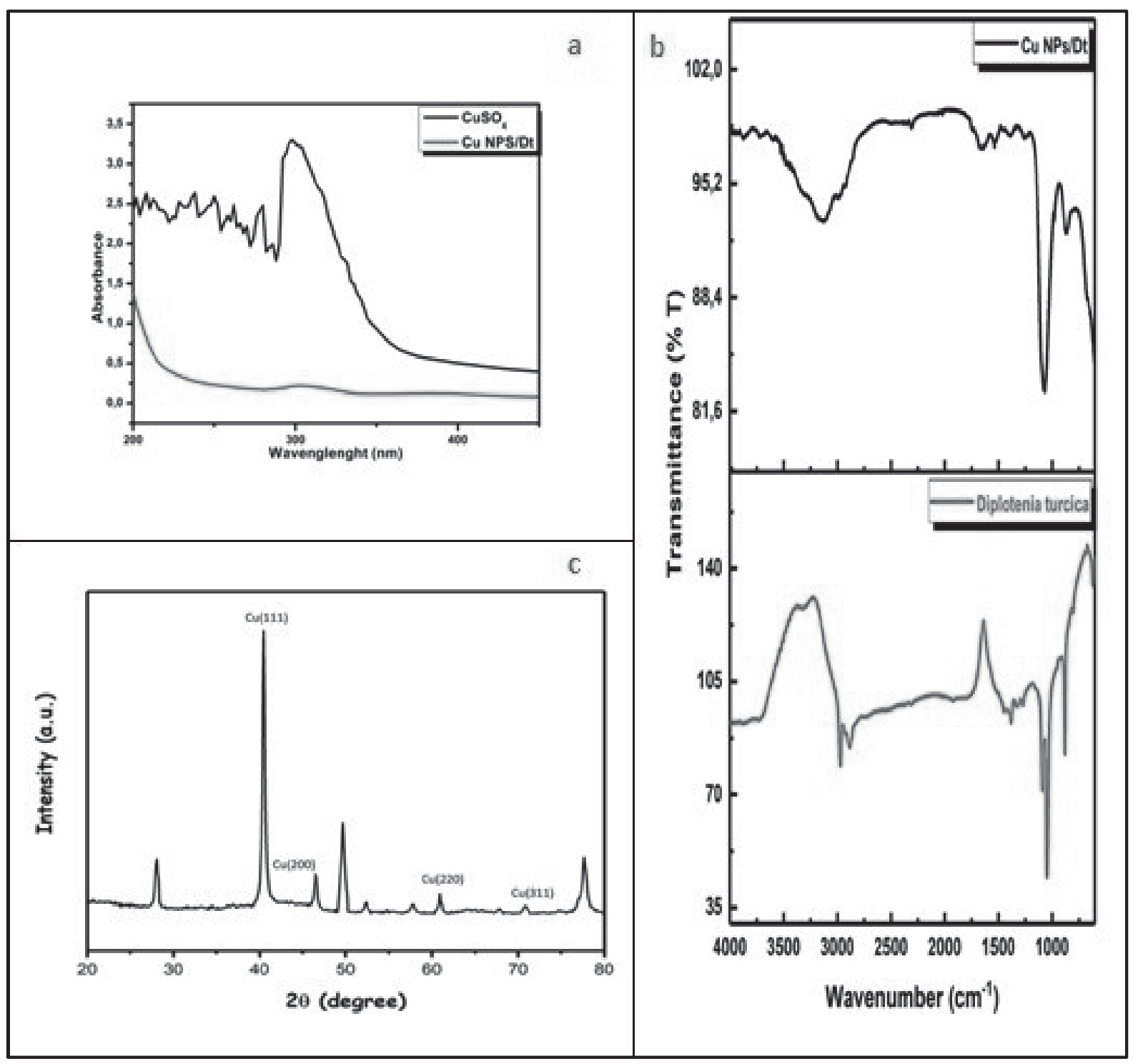

Fig. 1. a) UV-vis spectra of CuSO4 and Cu NPs/Dt samples, b) FT-IR spectra of Diplotaenia turcica plant extract and Cu NPs/Dt samples and c) XRD pattern of $\mathrm{Cu}$ NPs/Dt. 

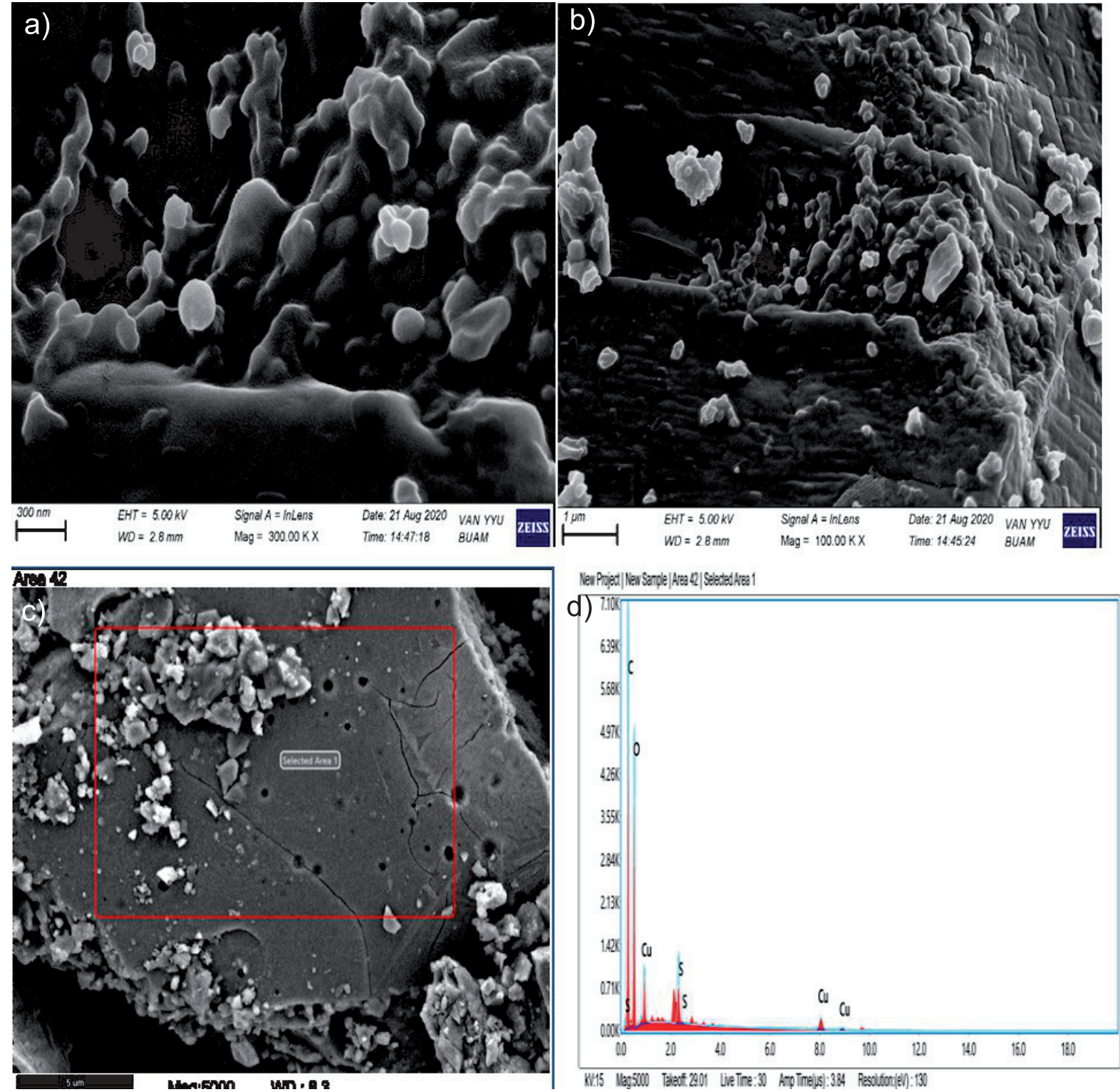

Fig. 2. (a-c) SEM images of $\mathrm{Cu}$ NPs/Dt sample taken at different scales. It shows the homogeneous distribution of Cu nanoparticles from SEM image at $300 \mathrm{~nm}$ scale. (d) EDX spectrum obtained from one of these images. EDX spectrum, on the other hand, clearly reveals the existence of $\mathrm{Cu}, \mathrm{C}, \mathrm{S}$ and $\mathrm{O}$ elements that form the structure of the $\mathrm{Cu}$ NPs/Dt sample.

As a result of these processes, the graph of $\mathrm{Cu}$ $\mathrm{NPs} / \mathrm{Dt}$ concentration versus increasing DPPH ethanol concentration was obtained. This graph is obtained using the above equation.

\section{Antimicrobial Activity of $\mathrm{Cu} \mathrm{NPs} / \mathrm{Dt}$}

Copper nanoparticles were obtained using Diplotaenia turcica extract and $\mathrm{CuSO}_{4}$. Antimicrobial activity of $\mathrm{Cu}$ NPs/Dt against some pathogenic microorganisms was investigated. The disk diffusion method was used to examine the antimicrobial effect [25]. Test microorganisms used in the study are given in Table 1 Microorganisms were obtained from Van Yüzüncü Yıl University, Faculty of Health Sciences.
$30 \mu \mathrm{L}$ of extract (1) and $30 \mu \mathrm{L}$ of nanoparticle (2) solution were absorbed into the blank discs and allowed to dry at room temperature. Pathogens previously activated in Nutrient Broth medium were transferred to Müller Hinton Agar medium and smear was performed. Neomycin (3) antibiotic was used for positive control. After the discs were placed, they were kept in the oven at $36.5-37^{\circ} \mathrm{C}$ for 48 hours for incubation. The zones formed at the end of the incubation period were measured and images were obtained.

\section{DNA Damage Preventive Effect of $\mathrm{Cu}$ NPs/Dt}

The damaging effect of $\mathrm{Cu}$ NPs/Dt on DNA was investigated. Electrophoresis was performed by preparing a $1 \%$ agarose gel $[26,27]$. pBR322 plasmid 


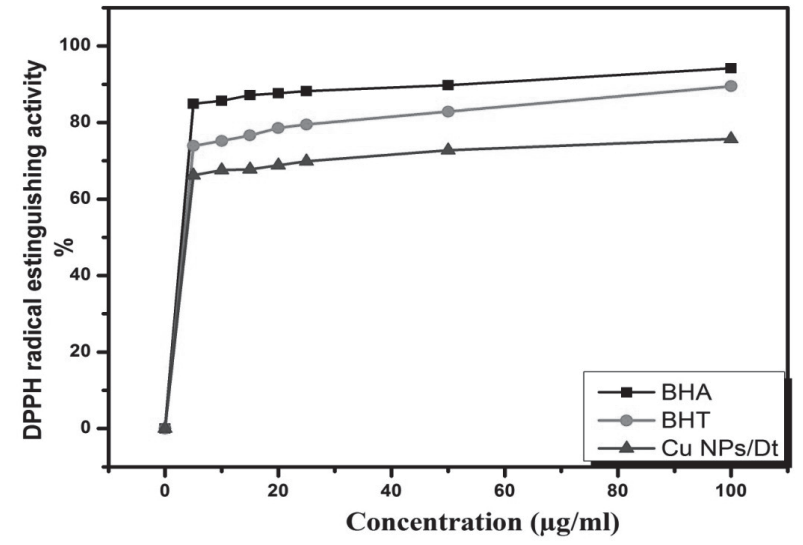

Fig. 3. DPPH scavenging activity values BHA (Butyl Hydroxy Anisole) 94.1558\%, BHT (Butyl Hydroxy Toluene) 89.4805\% and $\mathrm{Cu}$ NPs/Dt $75.7142 \%$.

DNA was used as nucleic acid in the study. Loading was made into five pits. Factors added to pits in electrophoresis process are given in Table 2 After the loading process was completed, 45 minutes of execution was done at 110 Volts. From the third well, copper nanoparticles were added at the rate of 50-100-250 mg/L $\mathrm{Cu}$ NPs/Dt, respectively. The results obtained were recorded.

\section{Results and Discussion}

\section{Characterization of Synthesized of Cu NPs/Dt}

SEM/SEM-EDX, FT-IR, XRD and UV-vis techniques were used for the structural and morphological characterization of $\mathrm{Cu}$ nanoparticles prepared by green synthesis using Diplotaenia turcica plant, respectively. Fig. 1a) shows the UV-vis spectra of $\mathrm{CuSO}_{4}$ and $\mathrm{Cu}$ NPs/Dt samples. Signals observed at $305 \mathrm{~nm}$ wavelength in the UV-vis spectrum of the $\mathrm{CuSO}_{4}\left(\mathrm{Cu}^{+2}\right)$ solution can be attributed to d-d transitions. On the

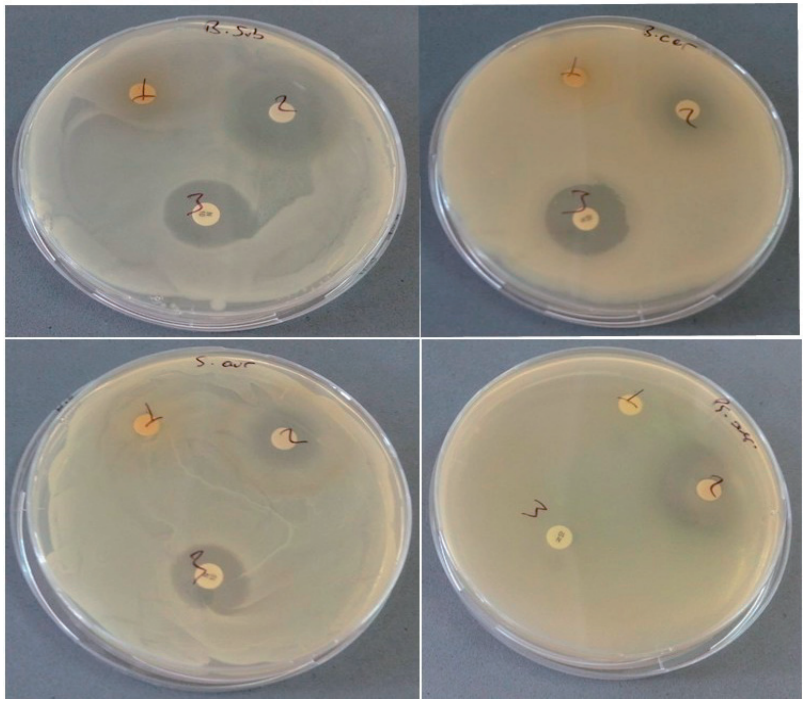

Fig. 4. Some images of antimicrobial activity (Extract $\rightarrow 1, \mathrm{Cu}$ $\mathrm{NPs} / \mathrm{Dt} \rightarrow 2$, Neomycin $\rightarrow 3$ )

other hand, it was observed that signals around 305 $\mathrm{nm}$ in the UV-vis spectrum of the $\mathrm{Cu}$ NPs/Dt sample completely disappeared. This situation reveals that the $\mathrm{Cu}^{+2}$ cation is largely reduced to metallic copper [28]. Fig. 1b) shows FT-IR spectra of a $\mathrm{Cu}$ NPs/Dt sample with Diplotaenia turcica plant extract. The signals observed at 1500 and $1550 \mathrm{~cm}^{-1}$ in the IR spectrum of Diplotaenia turcica plant extract originate from the functional groups of organic compounds (Gallic acid, Vanillin, Quercetin, Malic acid etc.) in the structure of Diplotaenia turcica sample. The peaks observed in the 3100 and $3300 \mathrm{~cm}^{-1}$ regions correspond to aromatic $\mathrm{C}-\mathrm{H}$ vibrations. In the FT-IR spectrum of the $\mathrm{Cu}$ NPs/Dt sample, it shows that there is a decrease in the peak intensities and shifts in some peaks. When the XRD pattern of the $\mathrm{Cu}$ NPs/Dt sample (Fig. 1c) is examined, the signals of $\mathrm{Cu}$ (111), $\mathrm{Cu}$ (200), $\mathrm{Cu}$ (220) and $\mathrm{Cu}(311)$ surfaces are seen at $36.54^{\circ}, 42.44^{\circ}, 61.57^{\circ}$ and $73.58^{\circ}$, respectively. It is understood that these

Table 3. Antimicrobial effect results.

\begin{tabular}{|c|c|c|c|}
\hline Tested Microorganisms & \multicolumn{3}{|c|}{ Zone of Inhibition (mm) } \\
\hline Bacteria & Extract (1) & Cu NPs/Dt (2) & Neomycin (3) \\
\hline Bacillus cereus ATCC 10876 & 8.10 & 13.20 & 20.25 \\
\hline Bacillus subtilis ATCC 6633 & 21.15 & 28.10 & 14.20 \\
\hline Escherichia coli ATCC 25952 & & 8.15 & \\
\hline Enterococcus faecalis ATCC 29212 & & 7.20 & 16.05 \\
\hline Pseudomonas aeruginosa ATCC 27853 & & 17.25 & \\
\hline Staphylococcus aureus ATTC 29213 & & 15.10 & 20.20 \\
\hline Fungus & & & \\
\hline Candida albicans ATTC 90028 & & & \\
\hline
\end{tabular}




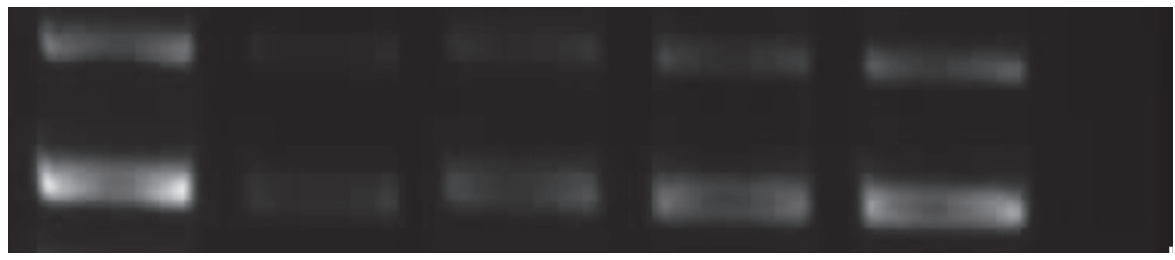

Fig. 5. Gel electrophoresis image.

values are quite compatible with the literature data [29]. Fig. 2(a-d) shows SEM images of $\mathrm{Cu}$ NPs/Dt sample taken at different scales and EDX spectrum obtained from one of these images. It shows the homogeneous distribution of $\mathrm{Cu}$ nanoparticles from SEM image at $300 \mathrm{~nm}$ scale. EDX spectrum, on the other hand, clearly reveals the existence of $\mathrm{Cu}, \mathrm{C}, \mathrm{S}$ and $\mathrm{O}$ elements that form the structure of the $\mathrm{Cu}$ NPs/Dt sample.

\section{Antioxidant Activity of Cu NPs/Dt (DPPH)}

DPPH radical quenching method is one of the most used cheap, fast and safe spectrophotometric methods in antioxidant activity measurement [30]. It was determined that $\mathrm{Cu}$ nanoparticles obtained by using cellulosic walnut shell material showed a significant antioxidant activity (97.2\%) [31]. The antioxidant effect of copper nanoparticles synthesized by using Dioscorea bulbifera a medicinal plant, was investigated and it was observed that it showed $40.81 \pm 1.44 \%$ scavenging activity against DPPH radicals. [32]. In our current study, considering the values in the graphic, it is seen when looking at the radical quenching activity that $\mathrm{Cu}$ NPs/Dt has antioxidant properties. DPPH radical quenching activity is seen to be $75.7142 \%$ at $100 \mu \mathrm{g} / \mathrm{ml}$, giving better results as the concentration increases (Fig. 3). That is, the higher the concentration, the higher the DPPH radical quenching activity accordingly. This value was found as 94.1558-89.4805 for the positive controls BHA and BHT, respectively. As a result, it is seen that $\mathrm{Cu}$ NPs/Dt nanoclusters give a result close to these values when compared to BHA and BHT used as positive control and have a good radical quenching effect.

\section{Antimicrobial Activity of $\mathrm{Cu}$ NPs/Dt}

$\mathrm{Cu}$ nanoparticles, like other metallic nanoparticles, show their antibacterial effects by disrupting the membrane structure [33]. Pathogenic bacteria such as Bacillus subtilis are more sensitive to copper nanoparticles as they bind more strongly to $\mathrm{Cu}$, which has cell walls rich in amine and carboxyl groups [34]. Aygün et al., [35] found that nanoclusters have antimcrobial effects against seven different pathogens. In this study, it was determined that Diplotaenia turcica extract showed antibacterial effect against Bacillus cereus and Bacillus subtilis species. However, it was observed that Copper nanoparticles obtained by using plant extract and $\mathrm{CuSO}_{4}$ affected all test microorganisms and formed zones varying between $8.15 \mathrm{~mm}$ and $28.10 \mathrm{~mm}$. It was determined that $\mathrm{Cu} \mathrm{NPs} / \mathrm{Dt}$ have significant antimicrobial activity. Copper nanoparticles showed the best zone against Bacillus subtilis ATCC 6633 bacteria, while the lowest zone showed against Enterococcus faecalis ATCC 29212 bacteria. In addition, Copper nano clusters were determined to be more effective against Bacillus subtilis ATCC 6633 Pseudomonas aeruginosa ATCC 27853 Enterococcus faecalis ATCC 29212 pathogens than the antibiotic used as positive control. Although $\mathrm{Cu}$ NPs/Dt clusters showed a low level of antifungal effect against Candida albicans fungus, it was observed that they showed a strong antibacterial effect against the pathogenic bacteria used. Antimicrobial activity results are shown in Table 3 and some images related to antimicrobial activity are shown in Fig. 4.

\section{DNA Damage Preventive Effect}

It was determined that the nanostructures obtained using chamomile flower extract and $\mathrm{CuO}$ disrupted the DNA helix structure [36]. On the other hand, in our electrophoresis study, it was seen that $\mathrm{Cu}$ NPs/Dt had a protective effect on pBR322 plasmid DNA. The image obtained is shown in Fig. 5. When the banding formed is evaluated, it is clearly seen that there are differences between the strip with the control DNA and the strips to which the nano clusters are added. Accordingly, it was seen that $100-250 \mathrm{mg} / \mathrm{L}$ concentrations of $\mathrm{Cu}$ $\mathrm{NPs} / \mathrm{Dt}$ have the potential to prevent breaks in DNA.

\section{Conclusions}

It was determined that copper nanoparticles have an inhibitory effect against some pathogenic microorganisms. Moreover, it was determined that it formed zones more effective against some pathogen bacteria than the antibiotic used. The number of bacteria that cause antibiotic resistance is constantly increasing. Due to the antimicrobial effect of $\mathrm{Cu}$ NPs/Dt, it is thought that it can be developed as a bio agent for the treatment of some diseases. The antioxidant capacity of copper nanoclusters has shown very important results. In the study, it was observed that as the concentration of extraction increased, the radical quenching activity increased. Various breaks and 
damages in DNA can cause mutation. Some diseases, especially cancer, occur as a result of these situations. The agents used in the treatment of these diseases damage healthy cells and disrupt the DNA chain. In this study, it was observed that $\mathrm{Cu}$ NPs/Dt had an anti-damage effect on pBR322 plasmid DNA and its protective effect increased with the increase of nanoparticle concentration.

\section{Acknowledgements}

HS thanks Van Yüzüncü Y1l University Science Research Application Center for their contributions.

\section{Conflict of Interest}

The authors declare no conflict of interest.

\section{References}

1. JARAMILLO A.F., RIQUELME S.A., SÁNCHEZSANHUEZA G., MEDINA C., SOLÍS-POMAR S., ROJAS D., MONTALBA C., MELENDREZ M.F., PÉREZTIJERINA E. Comparative study of the antimicrobial effect of nanocomposites and composite based on poly (butylene adipate-coterephthalate) using $\mathrm{Cu}$ and $\mathrm{Cu} / \mathrm{Cu}_{2} \mathrm{O}$ nanoparticles and $\mathrm{CuSO}_{4}$. Nanoscale Research Lett. 14, 158, 2019.

2. LI C., IQBAL M., JIANG B., WANG Z., KIM K., NANJUNDAN A.K., WHITTEN A.E., WOOD K., YAMAUCHI Y. Pore-tuning to boost the electrocatalytic activity of polymericmicelle-templated mesoporous $\mathrm{Pd}$ nanoparticles. Chem. Sci. 14, 4054, 2019.

3. SINGH P., KIM Y.J., ZHANG D., YANG D.C. Biological synthesis of nanoparticles from plants and microorganisms. Trends Biotechnol. 34, 588, 2016.

4. RAO P.V., GAN S.H. Recent advances in nanotechnology based diagnosis and treatments of diabetes. Curr. Drug Metab. 16, 371, 2015.

5. HUSSAIN A., AHMAD M.N., JALAL F., YAMEEN M., FALAK S., NOREEN S., NAZ S., NAZIR A., IFTIKHAR S., SOOMRO G.A., IQBAL M. Investigating the Antibacterial Activity of POMA Nanocomposites. Pol. J. Environ. Stud. 28, 1, 2019.

6. AKHTAR M., PANWAR J., YUN Y.S. Biogenic synthesis of metallic nanoparticles by plant extracts. - ACS Sustain Chem. Eng. 1, 591, 2013.

7. ALHARBY H.F., METWALI E.M.R., FULLER M.P., ALDHEBIANI A.Y. Impact of application of zinc oxide nanoparticles on callus induction, plant regeneration, element content and antioxidant enzyme activity in tomato (Solanum lycopersicum mill.) under salt stress. Arch Biol Sci. 68, 723, 2016.

8. SINGH A., SINGH N.B., HUSSAIN I., SINGH H. Effect of biologically synthesized copper oxide nanoparticles on metabolism and antioxidant activity to the crop plants Solanum lycopersicum and Brassica oleracea var. botrytis. J. Biotechnol. 262, 11, 2017.

9. KUMAR T.S.S., MADHUMATHI K., RUBAIYA Y., DOBLE M. Dual mode antibacterial activity of ion substituted calcium phosphate nanocarriers for bone infections. Front. in Bioeng. and Biotech. 3, 59, 2015.

10. BEYTH N., HADDAD Y.H., DOMB A., KHAN W., HAZAN R. Alternative antimicrobial approach: Nano antimicrobial materials. Evidence-based Comp. and Alt. Med. 2015, 246012, 2015.

11. MURALI M., MAHENDRA C., NAGABHUSHANRAJASHEKAR N., SUDARSHANA M.S., RAVEESHA K.A., AMRUTHESH K.N. Antibacterial and antioxidant properties ofbiosynthesized zinc oxide nanoparticles from Ceropegia candelabrum L.-an endemic species. Spectrochim Acta Part A Mol. Biomol. Spectrosc. 179, 104, 2017.

12. AL-SHEDDI S., FARSHORI N.N., AL-OQAIL M.M., AL-MASSARANI S.M., SAQUIB Q., WAHAB R., MUSARRAT J., AL-KHEDHAIRY A.A., SIDDIQUI M.A. Anticancer potential ofgreen synthesized silver nanoparticles using extract of Nepeta deflersiana against human cervical cancer cells (HeLA). Bioinorg. Chem. Appl. 2018, 9390784, 2018.

13. NASROLLAHZADEH M., SAJADI S.M., Green synthesis of copper nanoparticles using Ginkgo biloba L. leaf extract and their catalytic activity for the Huisgen [3+2] cycloaddition of azides and alkynes at room temperature. J. Colloid Interface Sci. 457, 141, 2015.

14. VERGARA-FIGUEROA J., ALEJANDRO-MARTÍN S., PESENTI H., CERDA F., FERNÁNDEZ-PÉREZ A., GACITÚA, W. Obtaining nanoparticles of Chilean natural zeolite and its ion exchange with ccopper salt $\left(\mathrm{Cu}^{+2}\right)$ for antibacterial applications. Materials 12, 2202, 2019.

15. SHANKAR S., WANG L.F., RHIM J.W. Preparation and properties of carbohydrate-based composite films incorporated with $\mathrm{CuO}$ nanoparticles. Carbohydrate Polymers 169, 264, 2017.

16. TAMAYO L., AZÓCAR M., KOGAN M., RIVEROS A., PAEZ M. Copper-polymer nanocomposites: an excellent and cost-effective biocide for use on antibacterial surfaces. Mater. Sci. Eng. C. 69, 1391, 2016.

17. ALAVI M., KARIMI, N. Characterization, antibacterial, total antioxidant, scavenging, reducing power and ion chelating activities of gren synthesized silver, copper and titanium dioxide nano particles using Artemisia haussknechtii leaf extract. Artificial Cells, Nanomed. and Biotech. 46, 2066, 2018.

18. PALZA H. Antimicrobial polymers with metal nanoparticles. Int. J. Mol. Sci. 16, 2099, 2015.

19. REN G., HU D., CHENG E.W.C., REUS M.A.V., REIP P., ALLAKER R. P. Characterisation of copper oxide nanoparticles for antimicrobial applications. Int. J. Antimicrob. Agen. 33, 587, 2009.

20. ÖZDEK U., YILDIRIM S., DEĞER Y. The effect of Diplotaenia turcica root extract in streptozotocininduced diabetic rats. Turkish Journal of Biochemistry 45, 2019.

21. UCE I., TUNÇTURK M. Hakkâri'de doğal olarak yetişen ve yaygin olarak kullanılan bazı yabani bitkiler. Biy. Bil. Araşt. Derg. 7, 21, 2014.

22. ÖZDEK U., BAŞBUĞAN Y., YILDIRIM S., BOĞA M., FIRAT M., DEĞER Y. Activity, acute and sub-acute toxicity and safety assesment of the hydroalcholic root extract of Diplotaenia turcica. Indian J. of Animal Res. 52, $1688,2018$.

23. GURUNATHAN S., CHOI Y.J., KIM J.H. Antibacterial efficacy of silver nanoparticles on endometritis caused by Prevotella melaninogenica and arcanobacterum pyogenes in dairy cattle. Int. J. Mol. Sci. 19, 1210, 2018. 
24. BLOIS MS. Antioxidant determinations by the use of a stable free radical. Nature 181, 1199, 1958.

25. ANDRADE C., AUGUSTO F., VERCIK O., CRISTINA L., MONTEIRO F.J., RIGO S., CRISTINA E. Preparation, characterization and antibacterial properties of silver nano particleshydroxyapatite compositesby a simple and ecofriendly method. Ceramics International, 42, 2271, 2016.

26. VANTI G.L., KURJOGI M., BASAVESHA K.N., TERADAL N.L., MASAPHY S., NARGUND V.B. Synthesis and antibacterial activity of solanum torvum mediated silver nanoparticle against Xxanthomonas axonopodis pv. Punicae and Ralstonia solanacearum. J. Biotechnol. 309, 20, 2020.

27. MEYDAN I., KIZIL G., DEMIR H., TOPTANCI B.C., KIZIL M. In vitro DNA damage, protein oxidation protective activity and antioxidant potentials of almond fruit (Amygdalus trichamygdalus) parts (hull and drupe) using soxhlet ethanol extraction. Adv. Tradit. Med. 13, 8, 2020.

28. SARANYA S., ESWARI A., GAYATHRI E., ESWARI S., VIJAYARANI K. Green synthesis of metallic nanoparticles using aqueous plant extract and their antibacterial activity. Int. J. Curr. Microbiol. App. Sci. 6, 1834, 2017.

29. KHAN A., RASHID A., YOUNAS R., CHONG R.A. Chemical reduction approach to the synthesis of copper nanoparticles. Int. Nano. Lett. 6, 21, 2016.

30. DENG J., CHENG W., YANG G. A novel antioxidant activity index (AAU) for natural products using the DPPH assay. Food Chemistry 125, 1430, 2011.
31. SURENDRAKUMAR R., IDHAYADHULLA A., ALARIFI S., AHAMED N.A., KUMAR C.S. Antioxidant activity of Telmisartan-Cu(II) nanoparticles connected 2-Pyrimidinamine and their evaluation of cytotoxicity activities. BioMed Research International, 2020, 8872479, 2020.

32. GHOSH S., MORE P., NITNAVARE R., JAGTAP S., CHIPPALKATTI R., DERLE A., KITTURE R., ASOK A., KALE S., SINGH S., SHAIKH M.L. Antidiabetic and antioxidant properties of copper nanoparticles synthesized by medicinal plant Dioscorea bulbifera. Journal Nanomedicine Nanotechnology, S6, 1, 2015.

33. HANS M., ERBE A., MATHEWS S., CHEN Y., SOLIOZ M., MUCKLICH F. Role of copperoxides in contact killing of bacteria. Langmuir 29, 16160, 2013.

34. PELGRIFTAND R.Y., FRIEDMAN A.J. Nanotechnology as a ther apeutictool to combat microbial resistance. Adv. Drug Del. Rev. 65, 1803, 2013.

35. AYGUN A., ÖZDEMIR S., GULCAN M., CELLAT K., ŞEN F. Synthesis and characterization of Reishi mushroom-mediated greensynthesis of silver nanoparticles for the biochemical applications. Journal of Pharmaceutical and Biomedical Analysis 178, 112970, 2020.

36. DUMAN F., ÖÇSOY I., KUP F. Chamomile flower extract-directed $\mathrm{CuO}$ nanoparticle formation for its antioxidantand DNA cleavage properties. Materials Science \& Engineering C-Materials For Biological Applications 60, 333, 2016. 